\title{
A felvételi követelmény megváltozásának hatása a felsőoktatás területi rekrutációjára
}

\author{
The impact of change in admission requirements \\ on the territorial recruitment of higher education \\ POLÓNYI ISTVÁN
}

POLÓNYI István: egyetemi tanár, Debreceni Egyetem, Bölcsészettudományi Kar, Nevelés- és Művelődéstudományi Intézet; 4032 Debrecen, Egyetem tér 1.; istvan.polonyi@arts.unideb.hu; https://orcid.org/0000-0002-6683-7888

KULCSSZAVAK: felsőoktatási bejutási esély; kistérségi rekrutáció; felsőoktatás fővárosvidék szerinti rekrutációja

ABSZTRAKT: A 2020. évi felsőoktatási felvételi - sokak számára meglepetést okozva - jelentős visszaesést hozott mind a jelentkezők, mind a felvettek számában. Ebben az írásban - az okok rövid felvillantása mellett - azzal foglalkozom, hogy a létszámcsökkenés milyen hatással van a felsőoktatás területi rekrutációjára. A problémakör három metszetét elemzem: a bejutási esélyek változásának kistérségi hatását, ehhez kapcsolódóan a hátrányos helyzetű kistérségek fiataljainak bekerülését, valamint a felsőoktatási szféra főváros-vidék rekrutációjában tapasztalható változásokat. ${ }^{1}$ Egy korábbi tanulmányomban megállapítottam, hogy 2013 és 2017 között romlott az alap- (és osztatlan) nappali képzésre történő bekerülés esélye a leghátrányosabb helyzetű kistérségekből. Itt azt vizsgálom, hogy a felvételi eljárás 2020. évi változása nyomán hogyan alakultak a kilátások.

István POLÓNYI: full professor, Institute of Educational Studies and Cultural Management, Faculty of Arts, University of Debrecen; Egyetem tér 1., H-4032 Debrecen, Hungary; istvan.polonyi@arts.unideb.hu; https://orcid.org/0000-0002-6683-7888

KEYWORDS: access to higher education; micro-regional recruitment; recruitment of higher education by capital and countryside

ABSTRACT: The results of 2020 higher education enrolment have come as a surprise to many as the number of applicants and those enrolled have significantly declined. This study examines the impact of headcount reduction on the territorial recruitment of higher education. In a previous study, I found that the chances of young people living in the most disadvantaged micro-regions to enter basic (and undivided) full-time education deteriorated between 2013 and 2017.

The current analysis is based on data published by felvi.hu, which come from the higher education enrolment database. The data also include the number of applicants to and enrolment in higher education institutions by micro-region. The assessment of the economic and social situation of the micro-regions is based on the data of a 2009 CSO publication.

The paper first presents the change in higher education admission requirements, pointing out that the generalization of advanced graduation has caused a decrease in the number of applicants, and consequently in the number of admissions. The work then analyses three crosssections of territorial recruitment of higher education. First, it examines the micro-regional impact of changes in entry opportunities, presenting changes in the micro-regional distribution of applicants and admissions. The paper then analyses the change in the enrolment of young people

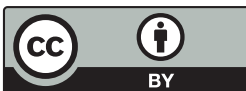


in the most disadvantaged micro-regions by comparing it with the chances of young people in the best-off micro-regions. Finally, the study examines how the tightening of admission requirements has affected the distribution of recruitment in the higher education sector between the capital and the countryside.

The study concludes that tightening the admissions system has had several consequences. Changes in access opportunities are differentiated for both micro-regions and institutions, resulting in restructuring.

One of the important consequences of this restructuring is that, although their chances of entry are increasing due to the large reduction in numbers, access to higher education for young people from disadvantaged regions is declining. The other consequence is that the tightening of the admission system will also restructure the institutional system, as a result of which the dominance of the capital's institutions will further increase. The paper analyses three sections of these processes, (1) micro-regional consequences of changes in access opportunities, (2) the related entry of young people from disadvantaged micro-regions, (3) changes in the recruitment of capital and rural institutions in the higher education sector".

\section{Adatok}

Az elemzés a felvi.hu által közreadott, felvételi adatbázisból származó adatokra épül. Ezek tartalmazzák 2008 óta az adott tanévre, általános, pót- és keresztféléves felvételi eljárás keretében jelentkezett és felvett felsőoktatási hallgatók számát. Bár a vizsgált felsőoktatáspolitikai intézkedés hatása a teljes felvett létszámra kiterjedt, jelen elemzésben csupán az egész felvételi folyamat legnagyobb részét kitevő általános eljárás tapasztalataira térek ki. ${ }^{2} \mathrm{~A}$ felvi.hu kistérségi megoszlásban is közreadja a felsőoktatási jelentkezésre és felvételre vonatkozó adatokat. Elemzésem erre támaszkodik: az összes első helyen jelentkezett és felvett, az alap- (és osztatlan) képzésre, nappali tagozatos munkarendre első helyen ${ }^{3}$ jelentkezett és felvett, továbbá az államilag finanszírozott képzésre első helyen jelentkezett és felvett hallgatók adatait használtam. A kistérségek gazdasági, társadalmi helyzetének megítéléséhez - mivel közismert, hogy a kistérségi statisztikai adatszolgáltatás megszűnt - a Központi Statisztikai Hivatal egy régebbi kiadványának adatait használtam (KSH 2008). ${ }^{4}$ A vizsgált leghátrányosabb és legjobb helyzetü kistérségeket a Melléklet 1. táblázata tartalmazza.

\section{Előzmények és következmények}

Az oktatáspolitika 2014-ben - 2020. évi bevezetéssel - mélyreható változtatást határozott el a felsőoktatási felvételi jogszabályokban. A Kormány 335/2014. (XII. 18.) Korm. rendelete (a felsőoktatási felvételi eljárásról szóló 423/2012. (XII. 29.) Korm. rendelet módosításáról) 10. § (2) bekezdésében jelentősen módosította a felvételi feltételeit. Eszerint „alapképzésre, osztatlan képzésre (...) az a jelentkezo vehető fel, aki a) legalább B2 szintű, általános nyelvi, komplex nyelvvizsgával, vagy azzal egyenértékű okirattal rendelkezik és b) legalább egy emelt szintű 
érettségi vizsgát tett vagy felsőfokú végzettséget tanúsító oklevéllel rendelkezik." (A b) pontot nem kell alkalmazni a művészeti képzési területre jelentkezőkre.) A rendelkezést azonban csak részben vezették be, mert 2019 novemberében a 2019. (XI. 14.) Korm. rendelet (a felsőoktatási felvételi eljárással összefüggésben egyes kormányrendeletek módosításáról) 5 . § szerint „nem lép hatályba a 335/2014. (XII. 18.) Korm. rendelet 10. § (2) bekezdése." Tehát az utolsó pillanatban eltörölték a kötelező nyelvvizsga követelményét. Az emelt szintű érettségi általánosan kötelező előírását ugyanakkor megtartották, így az addig csak a szakok egy részénél kötelező emelt szintủ érettségi elvárást valamennyi szakra kiterjesztették. A szeptemberben kezdődő képzésekre december második felében indul és február közepén zárul a jelentkezés az ún. általános felvételi eljárás keretében, tehát a módosítás éppen időben, egy hónappal a jelentkezések kezdete előtt történt. A következmény azonban mégis rendkívül jelentős volt (1. táblázat).

2020-ban a jelentkezők száma 20,5 ezer fővel csökkent. Ilyen kevesen nem jelentkeztek még, mióta központi felvételi rendszer van. A jelentkezettek között kicsit több mint hétezret tett ki a 18 éves vagy fiatalabb és a 19 éves korosztály együttes létszámcsökkenése: ők azok, akik nagyrészt a felvételi évében érettségiztek. (Fontos hozzátenni, hogy a folyamatokban a demográfia nem játszhatott jelentősebb szerepet, mivel a 17 éves népesség létszáma 2018 és 2020 között mindössze néhány száz fővel változott). A felvett létszámban - a felvételi rendszer sajátosságai miatt, melynek keretében az intézményi kapacitásokat igyekeznek feltölteni a „vonalhúzás” során - már tompítottabban jelentkeztek a hatások. A 2020. évi általános eljárásban felvettek számára is igaz ugyanakkor, amit a jelentkezőkről írtam: ilyen kevés hallgatót nem vettek még fel, mióta központi felvételi rendszer müködik. Az összes felvett száma tízezer fővel, a 19 évesek és fiatalabbak száma mintegy 2,1 ezer fövel csökkent.

Kisebb elemzéssel azt is észre lehet venni, hogy a létszámszükítés elszenvedői nagyobb részt a részidős, első diplomaszerzésre jelentkezők voltak (Melléklet 2. táblázata). Az első diplomaszerzésre irányuló jelentkezéseket, azaz az alap- és osztatlan képzésre első helyen jelentkezők számát (valamennyi tagozaton) megvizsgálva, a csökkenés mértéke kicsit több mint 19,5 ezer fö. Ezer fö híján tehát a teljes csökkenés az első diplomára irányuló képzéseknél figyelhető meg: a mesterképzés és a felsőoktatási szakképzés esetében alig volt visszaesés. Szembetűnő, hogy miközben a nappali alap- és osztatlan képzésre felvettek száma 12 százalékkal csökkent, addig a részidős képzésre felvett hallgatóké több mint egyharmadával zsugorodott.

Viszonylag egyszerü vizsgálattal rá lehet jönni, hogy elsősorban nem a nyelvvizsga körüli bonyodalom riasztotta vissza a jelentkezőket, hanem az emelt szintü érettségi hatása volt jelentősebb. A részidős képzésre jelentkezők esetében ez az összefüggés egészen biztos, hiszen többüknek le kellene tenni a vizsgát, ami - az ő esetükben - újabb érettségit jelentene. ${ }^{5}$ 
1. táblázat: Az általános eljárás keretében jelentkezők és felvettek létszámának alakulása Changes in the number of applications and admissions to higher education (during the general procedure) tv Usszesjelentkezo jelentkezo az elozo Usszesfelvett relvettek az elozo Bejutasi esely év\%-ában év \%-ában

(felvett

\begin{tabular}{|c|c|c|c|c|c|}
\hline & & & & & /jelentkezett) \\
\hline 2001 & 148880 & - & 98031 & - & $65,85 \%$ \\
\hline 2002 & 164703 & $111 \%$ & 109470 & $112 \%$ & $66,47 \%$ \\
\hline 2003 & 160217 & $97 \%$ & 106376 & $97 \%$ & $66,39 \%$ \\
\hline 2004 & 167371 & $104 \%$ & 109851 & $103 \%$ & $65,63 \%$ \\
\hline 2005 & 150232 & $90 \%$ & 103364 & $94 \%$ & $68,80 \%$ \\
\hline 2006 & 132771 & $88 \%$ & 94142 & $91 \%$ & $70,91 \%$ \\
\hline 2007 & 108928 & $82 \%$ & 81637 & $87 \%$ & $74,90 \%$ \\
\hline 2008 & 96991 & $89 \%$ & 81108 & $99 \%$ & $83,60 \%$ \\
\hline 2009 & 127306 & $131 \%$ & 94724 & $117 \%$ & $74,40 \%$ \\
\hline 2010 & 140308 & $110 \%$ & 98246 & $104 \%$ & $70,00 \%$ \\
\hline 2011 & 140954 & $100 \%$ & 98144 & $100 \%$ & $69,60 \%$ \\
\hline 2012 & 110616 & $78 \%$ & 80136 & $82 \%$ & $72,40 \%$ \\
\hline 2013 & 95447 & $86 \%$ & 72679 & $91 \%$ & $76,10 \%$ \\
\hline 2014 & 106175 & $111 \%$ & 74182 & $102 \%$ & $69,90 \%$ \\
\hline 2015 & 105646 & $100 \%$ & 72260 & $97 \%$ & $68,40 \%$ \\
\hline 2016 & 111219 & $105 \%$ & 74901 & $104 \%$ & $67,30 \%$ \\
\hline 2017 & 105868 & $95 \%$ & 72758 & $97 \%$ & $68,70 \%$ \\
\hline 2018 & 107700 & $102 \%$ & 75291 & $103 \%$ & $69,90 \%$ \\
\hline 2019 & 112033 & $104 \%$ & 78980 & $105 \%$ & $70,50 \%$ \\
\hline 2020 & 91460 & $82 \%$ & 68112 & $86 \%$ & $74,50 \%$ \\
\hline
\end{tabular}

Forrás: A felvi.hu adatok alapján saját számitás

\section{A kistérségi rekrutáció jellemzőinek változása}

Ha minden kistérségre kiszámoljuk a bejutási esélyt (azaz elosztjuk az adott kistérségből felvettek számát a jelentkezők számával), akkor 2020-ban elég jellegzetes elmozdulást tapasztalunk 2019-hez viszonyítva (1. ábra). Az egyik fontos változás, hogy a bejutás esélye a 2019. évi 70,5 százalékról 74,4 százalékra nőtt. Ez azonban nem meglepő, mivel a felvételi eljárás sajátosságai miatt - a felvételi során az intézményi kapacitásokat feltöltik - a kevesebb jelentkezőből arányaiban mindig többet vesznek fel. A korábbi, 2013. évi csökkenésnél például 76\%, a 2008. évi csökkenésnél pedig $84 \%$ volt a bejutási arány ${ }^{6}$ (1. táblázat). 
1. ábra: A kistérségek bejutási esély szerinti eloszlása 2019-ben és 2020-ban, az összes, általános eljárás keretében jelentkező és felvett esetében

Micro-regional distribution of entry chances in 2019 and 2020 for all applications and admissions (during the general procedure)

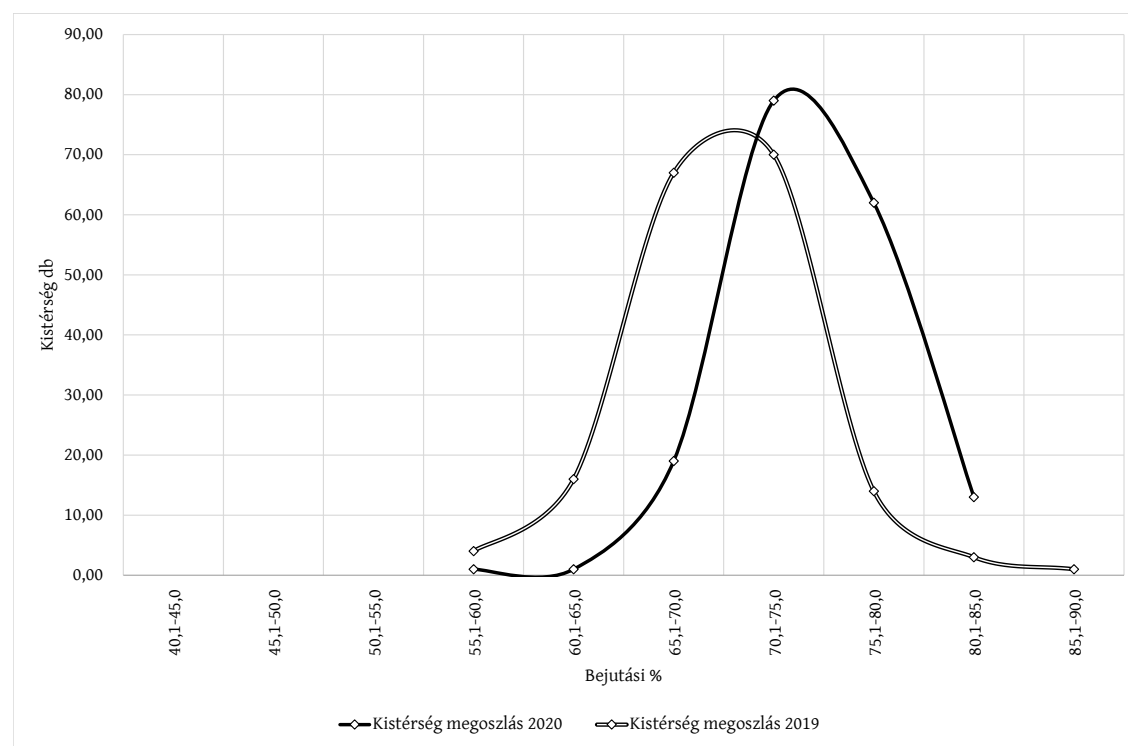

Forrás: A felvi.hu adatai alapján saját számítás és szerkesztés

A másik szembetűnő következmény, hogy a kistérségek bejutási esélyek szerinti eloszlása - az esélynövekedés miatt - jobbra, azaz a nagyobb esélyek felé tolódik. Egyben „kihegyesedik”, ami arra utal, hogy megnövekedett azon kistérségek aránya, amelyekben a bejutási esély az átlag felett alakul (1. ábra). Hasonló eltolódást tapasztalunk az alap- és osztatlan képzésre jelentkezők esetében (2. ábra), miközben az államilag finanszírozott képzésekre jelentkezettek bejutási esélyei alapján kirajzolódó kép részben eltér az előző kettőtől. Itt is mutatkozik eltolódás a magasabb esélyek felé, de nincs „kihegyesedés” (3. ábra).

Ezt a „kihegyesedést” a szórások elemzésével úgy fogalmazhatjuk meg szabatosabban, hogy 2019-ről 2020-ra a kistérségek fiataljaira jellemző bekerülési esélyek átlaga megnövekedett, ugyanakkor lecsökkent az eloszlásuk terjedelme és szórása. Az is látszik, hogy miközben a bejutási esélyek átlagának növekedése az államilag finanszírozott helyekre jelentkezettek esetében volt a legnagyobb, az átlag értéke még így is ott a legkisebb, és a szórás változása is ebben az esetben a legmérsékeltebb (2. táblázat).

A jelentkezési létszámnak az emelt szintű érettségi bevezetése miatt bekövetkezett csökkenése tehát minden vizsgált képzési formánál a bejutási esélyek növekedését eredményezte. Ez azonban - feltételezésünk szerint - nem járt a különböző kistérségekből jelentkező fiatalok esélyeinek azonos mértékű növekedésével. Ezt vizsgáljuk meg a következőkben. 
2. ábra: A kistérségek bejutási esély szerinti eloszlása 2019-ben és 2020-ban, az általános eljárás keretében alap- és osztatlan képzésre jelentkezők és felvettek esetében Micro-regional distribution of access chances in 2019 and 2020 for applications and admissions at basic and undivided training $s$ (during the general procedure)

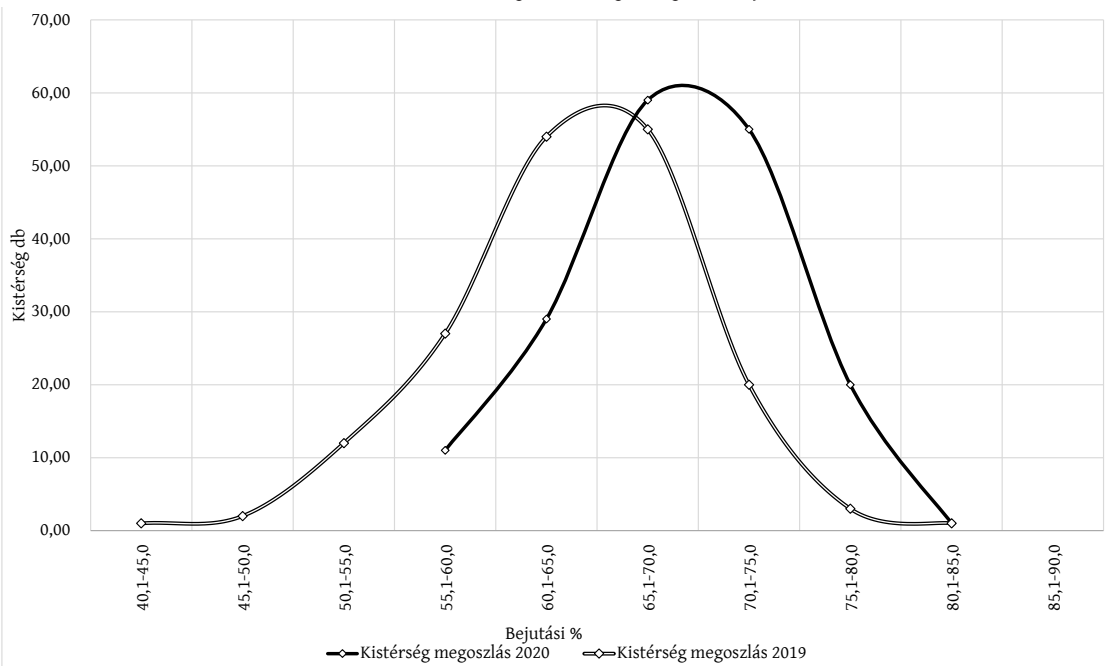

Forrás: A felvi.hu adatai alapján saját számítás és szerkesztés

3. ábra: A kistérségek bejutási esély szerinti eloszlása 2019-ben és 2020-ban, az általános eljárás keretében államilag finanszírozott képzésre jelentkezők és felvettek esetében Micro-regional distribution of access chances in 2019 and 2020 for applications and admissions at state-funded training (during the general procedure)

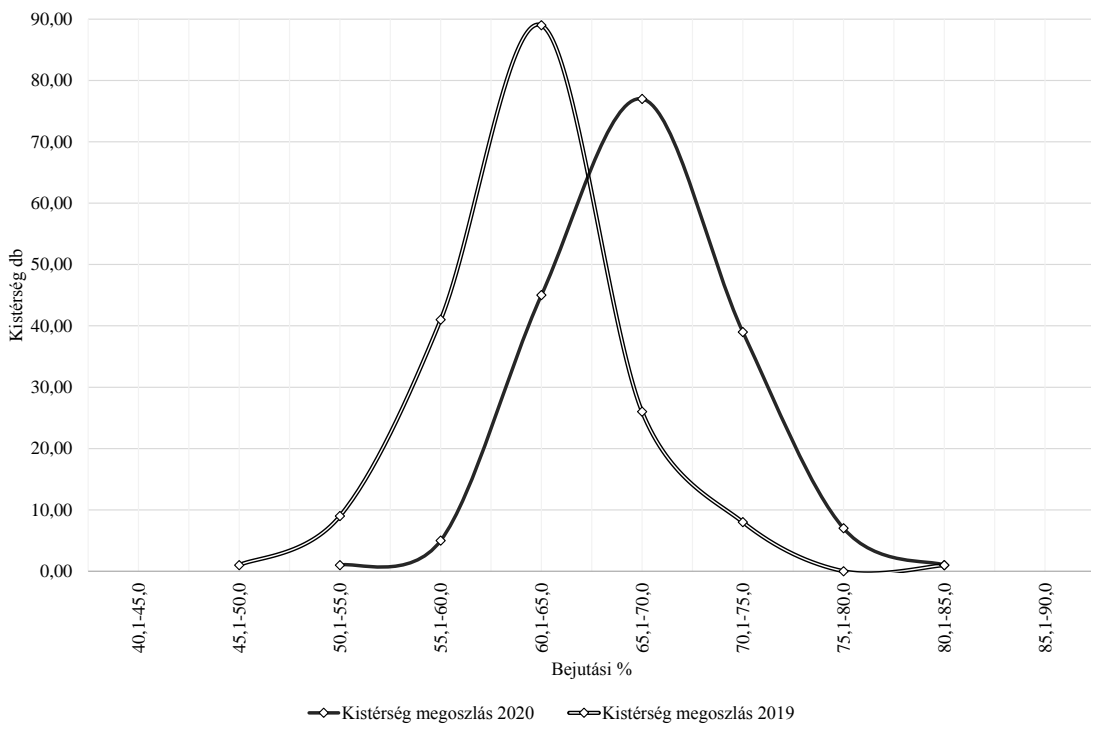

Forrás: A felvi.hu adatai alapján saját számítás és szerkesztés 
2. táblázat: A 2019. és a 2020. évi általános felvételi eljárásban jelentkezett fiatalok kistérségi megoszlásának néhány jellemzője

Some characteristics of the micro-regional distribution of young people who applied in the general recruitment procedure in 2019 and 2020

\begin{tabular}{|c|c|c|c|c|c|c|c|c|c|}
\hline \multirow[t]{2}{*}{$\begin{array}{l}\text { Az eloszlás } \\
\text { jellemzői }\end{array}$} & \multicolumn{3}{|c|}{ Összes jelentkező } & \multicolumn{3}{|c|}{ AONjelentkezö } & \multicolumn{3}{|c|}{$\begin{array}{c}\text { Államilag finanszírozott } \\
\text { helyre jelentkezó }\end{array}$} \\
\hline & 2019 & 2020 & $2020 / 19$ & 2019 & 2020 & $2020 / 19$ & 2019 & 2020 & $2020 / 19$ \\
\hline Átlag & 70,04 & 74,38 & $106 \%$ & 63,89 & 68,89 & $108 \%$ & 62,09 & 67,49 & $109 \%$ \\
\hline Terjedelem & 30,00 & 25,00 & $83 \%$ & 40,00 & 25,00 & $63 \%$ & 35,00 & 30,00 & $86 \%$ \\
\hline Szórás & 4,75 & 4,18 & $88 \%$ & 6,26 & 5,40 & $86 \%$ & 4,76 & 4,63 & $97 \%$ \\
\hline
\end{tabular}

Forrás: felvi.hu adatok alapján saját számítás

\section{A leghátrányosabb helyzetű kistérségek fiataljainak bejutási esélyei}

A bejutási esélyek hátrányos helyzetű régiókra koncentráló vizsgálata lehetőséget teremt a hátrányos helyzetủ fiatalok felsőoktatásba kerülésének valamilyen szintű megítélésére. A hátrányos helyzetű lakóhely és a hátrányos helyzet közötti összefüggés természetesen sokrétű, nem triviális. Mint Garami írja: „A hátrányosabb (térségi) környezeti feltételek adott esetben 'visszahúzhatják' azokat a családokat és iskolákat is, melyek adottságaik alapján jobb eredmények elérésére is képesek lennének. A kedvezőtlenebb adottságokkal rendelkező térségekben 'összecsúsznak' a kedvezőtlen térségi adottságokból, valamint a kedvezőtlen társadalmi háttérből adódó hátrányok. A hátrányosabb helyzetet teremtő kistérségi jellemzők erősebben tudják kifejteni negatív hatásukat, mint az előnyösebb mutatók a maguk kedvezőbb hatását. Ez pedig a hátrányok, az előnytelen adottságok olyan szintü 'halmozódását' okozhatja, amely komolyan akadályozhat bármilyen térségi szintű fejlesztést." (Garami 2013, 209.). Noha a hátrányos helyzetű térségben élés és a hátrányos helyzet közé nem tehető egyenlőségjel, a hátrányos helyzetü kistérségekben élő fiatalok felsőoktatásba kerülése mégis az előbbinek fontos „lakmuszpapírja” lehet. A következőkben a leghátrányosabb helyzetű kistérségekben élő (ott regisztrált állandó lakóhellyel rendelkező) fiatalok felsőoktatásba jutásának jellemzőit vizsgáljuk. Összehasonlítjuk a leghátrányosabb és a legjobb helyzetű kistérségekből jelentkezett és felvett fiatalok bekerülési esélyeit.

Az elemzést a 2008. évi besorolás (KSH 2008) alapján, a leghátrányosabb helyzetű utolsó 20 , a legjobb helyzetű első 20 , valamint az összes kistérségre vonatkozóan végeztem el. Mint korábban láttuk, a 2020. évi felvételi feltételeinek szigorítása nyomán a jelentkezési létszám csökkent, és ennek nyomában növekedtek a bejutási esélyek. Ezzel párhuzamosan növekedett a 20 leghátrányosabb helyzetű kistérségből történő bekerülés valószínűsége is. Ugyanakkor a leghátrányosabb kistérségek bejutási esélyei elmaradnak az összes kistérség átlagától (4. ábra). 
4. ábra: A 20 leghátrányosabb helyzetű kistérségből jelentkezők bejutási esélye 2019-ben és 2020-ban, összehasonlítva az összes kistérség átlagával

Change in the entry chances of applicants from the 20 most disadvantaged micro-regions in 2019, 2020, compared to the average of all micro-regions

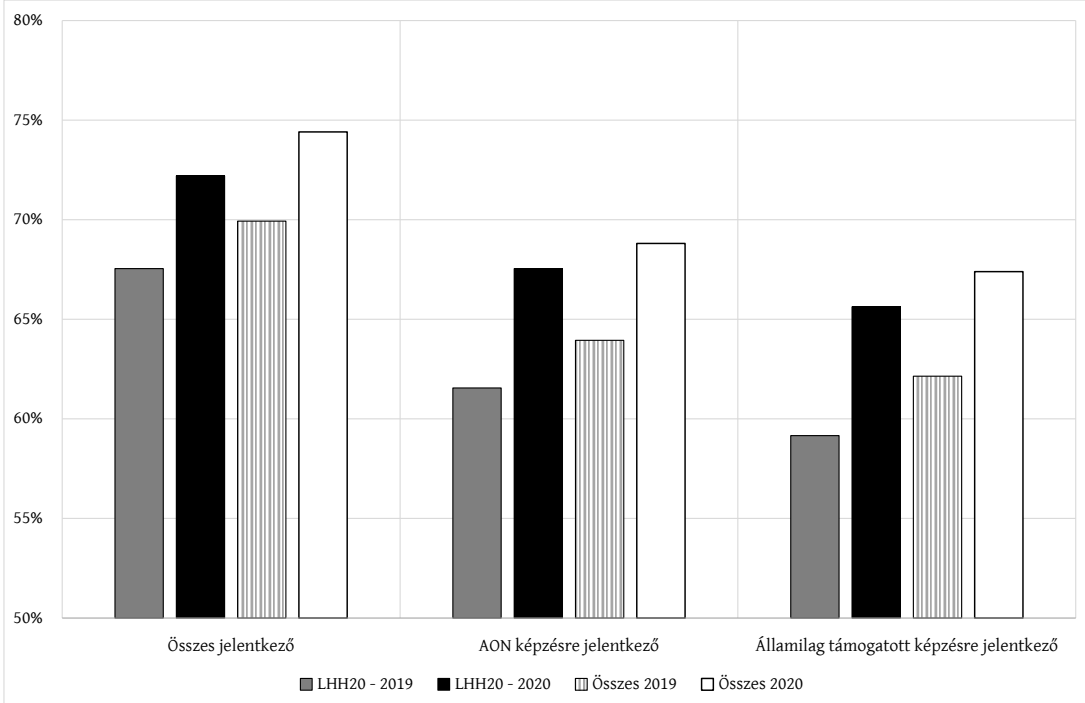

Forrás: A felvi.hu adatai alapján saját számítás és szerkesztés

5. ábra: A 20 legjobb helyzetű kistérségből jelentkezők bejutási esélye 2019-ben és 2020-ban, összehasonlítva az összes kistérség átlagával Change in the entry chances of applicants from the 20 best placed micro-regions in 2019, 2020 compared to the average of all micro-regions

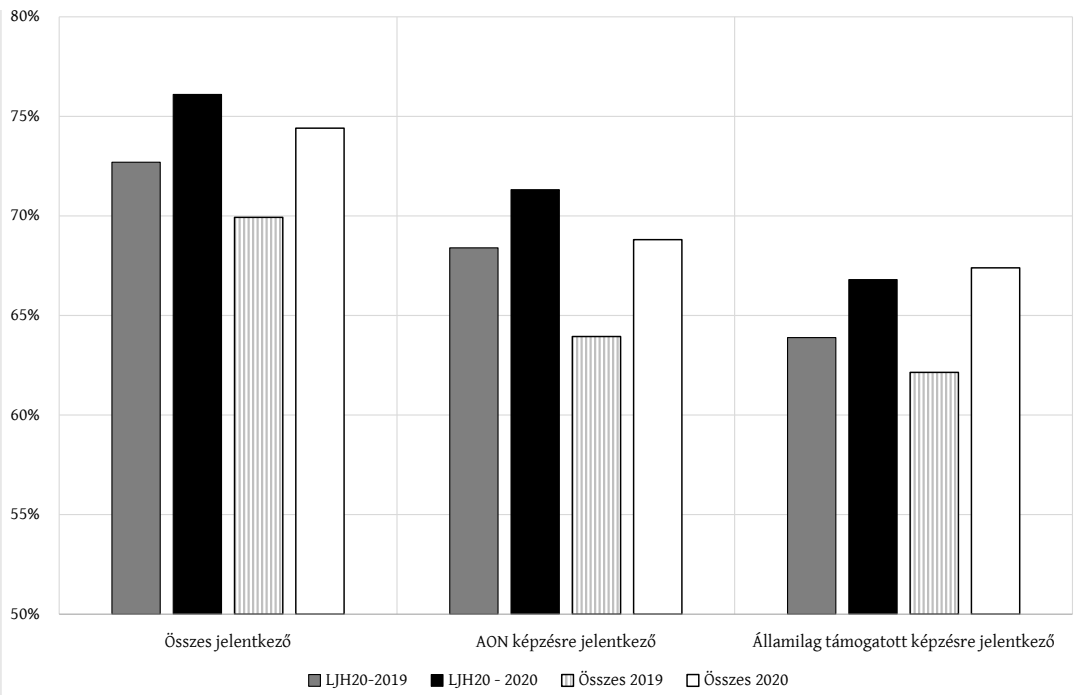

Forrás: A felvi.hu adatai alapján saját számítás és szerkesztés 
A 20 legjobb helyzetű kistérségből történő bekerülés valószínűsége is emelkedett, bár az előzővel messze nem azonos mértékben. A legjobb helyzetű kistérségek fiataljainak bejutási esélye a felsőoktatásba viszont mindenhol magasabb, mint az összes kistérség átlaga (5. ábra).

Jóllehet, a leghátrányosabb helyzetű kistérségekben a bejutási esély növekedése nagyobb volt, mint a legjobb helyzetű kistérségek esetében, előbbiek e növekedési többlet ellenére sem érték el az utóbbiak esélyszintjét (3. táblázat). A leghátrányosabb helyzetű fiatalok felsőoktatásba kerülési esélye elmarad a legjobb helyzetű kistérségek fiataljai mögött (Polónyi 2018a).

3. táblázat: A 20 LHH és 20 LJH kistérségből jelentkezők bejutási esélye 2019-ben és 2020-ban Entry chances of applicants from the 20 most disadvantaged and the 20 best positioned micro-regions in 2019 and 2020

\begin{tabular}{lccc} 
& Usszes jelentkezo & $\begin{array}{c}\text { AUN kepzesre } \\
\text { jelentkező }\end{array}$ & $\begin{array}{c}\text { Allamilag tamogatott } \\
\text { képzésre jelentkező }\end{array}$ \\
\hline LHH20 - 2019 & $67,5 \%$ & $61,1 \%$ & $59,0 \%$ \\
LHH20 - 2020 & $72,2 \%$ & $67,5 \%$ & $65,6 \%$ \\
Változás LHH20 & $4,70 \%$ & $6,40 \%$ & $6,60 \%$ \\
\hline LJH20 - 2019 & $72,7 \%$ & $68,4 \%$ & $63,9 \%$ \\
LJH20 - 2020 & $76,3 \%$ & $71,6 \%$ & $67,1 \%$ \\
Válttozás LJH20 & $3,60 \%$ & $3,20 \%$ & $3,20 \%$ \\
\hline Összes kistérség 2019 & $69,93 \%$ & $63,94 \%$ & $62,15 \%$ \\
Összes kistérség 2020 & $74,41 \%$ & $68,81 \%$ & $67,40 \%$ \\
\hline Változás összes kistérség & $4,48 \%$ & $4,87 \%$ & $5,25 \%$ \\
\hline
\end{tabular}

Forrás: Felvi.hu adatai alapján saját számítás

Érdemes azonban a százalékok mögé is bepillantani! Bár a 2020. évi és a 2019. évi adatok összehasonlíthatóságához feltételeznünk kell számos tényező változatlanságát, az látszik, hogy a legjobb helyzetü kistérségekben a felvettek száma egyedül az államilag támogatott létszám esetében csökkent egy nagyon kicsit (7 fővel), a többi kategóriában növekedés figyelhető meg. A leghátrányosabb helyzetủ kistérségekben ugyanakkor minden felvett létszám csökkent (4. táblázat). ${ }^{7}$ A bejutás esélyének - jelentkezési számok csökkenéséből adódó - növekedése tehát nem létszámbővülést, hanem csökkenést hozott a hátrányos helyzetü kistérségek esetében, míg a legjobb helyzetű kistérségekben nem okozott zsugorodást. Szembetűnő, hogy míg a hátrányos helyzetű kistérségekben 6 023-ról 4256 főre esett a jelentkezők száma (és a felvettek száma is csökkent 1000 fővel), addig a legjobb helyzetben lévő térségekben 33 ezerről 36 ezerre nőtt a jelentkezők száma (és a felvettek száma is közel 1000 fővel gyarapodott). 
4. táblázat: A 20 LHH és 20 LJH kistérségből jelentkezők és felvettek száma 2019-ben és 2020-ban

Number of applications and admissions from the 20 most disadvantaged and 20 best positioned micro-regions in 2019 and 2020 2019 2020

\begin{tabular}{llcccr} 
& & Jelentkezett & Felvett & Jelentkezett & Felvett \\
\hline LHH 20 & Összes jelentkezó & 6023 & 4108 & 4256 & 3134 \\
LHH 20 & AON képzésre jelentkezó & 3551 & 2282 & 2477 & 1746 \\
LHH 20 & Államilag támogatott & 5407 & 3236 & 3912 & 2590 \\
& képzésre jelentkező & & & & \\
\hline LJH 20 & Összes jelentkező & 33081 & 24761 & 36005 & 25607 \\
LJH 20 & AON képzésre jelentkező & 21006 & 14950 & 22256 & 14961 \\
LJH 20 & Államilag támogatott & 29604 & 19085 & 31301 & 19078 \\
& képzésre jelentkező & & & & \\
\hline
\end{tabular}

Forrás: A felvi.hu adatai alapján saját számitás

\section{Az intézménycsoportok rekrutációjának változása}

A 2020. évi felvételi alapvetően hatott az intézmények rekrutációjára is, hiszen az egyes intézményeknek megvan a maga területi (és társadalmi) beiskolázási körzete (Polónyi 2012). Az adatokra tekintve (5. táblázat) szembetűnő, hogy a művészeti egyetemek nem vesztettek hallgatót; ez nem csoda, hiszen rájuk nem vonatkozott az emelt szintű érettségi követelménye. Az is egyértelműen látszik, hogy a felsőoktatáspolitikai lépés vesztesei a vidéki intézmények: a vidéki alsó középosztály gyermekei vannak kiszorulóban a döntés nyomán, ami nyilván azzal áll összefüggésben, hogy ezek a fiatalok nem túl erős középiskolákba járnak, és számukra nehezebb emelt szintű érettségit tenni, miután a szüleik sem sokat tudnak különórákra áldozni. A vidéki egyetemek 10 százalékponttal, a vidéki alkalmazott tudományegyetemek csaknem 30 százalékponttal vesztettek több hallgatót, mint a fővárosiak.

Az adatokat kissé alaposabban megvizsgálva (Melléklet 3. táblázata) az látszik, hogy a vidéki tudományegyetemeken növekedett a bejutás esélye, mely azonban

5.táblázat: A felvettek számának alakulása 2019-ben és 2020-ben, intézménycsoportonként Change in the number of admissions in 2019 and 2020 by types of institutions

$$
\text { Fövárosi }
$$

Vidéki

\begin{tabular}{lrrrrrc} 
& \multicolumn{1}{c}{2019} & \multicolumn{1}{c}{2020} & \multicolumn{1}{c}{$\%$} & \multicolumn{1}{c}{2019} & \multicolumn{1}{c}{2020} & \multicolumn{1}{c}{$\%$} \\
\hline Tudományegyetemek & 30978 & 28865 & $93 \%$ & 31599 & 26266 & $83 \%$ \\
Művészeti egyetemek & 991 & 995 & $100 \%$ & & & \\
Alkalmazott tudományegyetemek & 7683 & 7143 & $93 \%$ & 6383 & 4129 & $65 \%$ \\
Főiskolák & 605 & 292 & $48 \%$ & 741 & 513 & $69 \%$ \\
\hline
\end{tabular}


nem tudta ellensúlyozni a jelentkezők számának csökkenését. A vidéki alkalmazott tudományegyetemeken a bejutási esély növekedése elmaradt a fővárosiakétól, ráadásul a jelentkezők száma is jelentősen csökkent, ebből következett a több mint egyharmadnyi arányú térvesztés. A fơvárosi és a vidéki főiskolákon a jelentkezők arányának csökkenése nagyjából azonos mértékü, azonban a budapesti föiskolákon még a bekerülési esély is csökkent, a radikális veszteség ebből adódik. A tendenciák mögött hallgatói választások állnak: a vidéki alkalmazott tudományegyetemeket, valamint a fóvárosi főiskolákat (ahol a bejutási esély alig nő, vagy csökken) egyre kevesebb és egyre gyengébb tanulók választják.

Végeredményben mindezek nyomán nyilvánvalóan tovább fog növekedni a magyar felsőoktatás eddig is jellemző főváros-centrikussága (6. táblázat).

6. táblázat: A hallgatók létszámának megoszlása főváros és vidék között a 2018/2019-es tanévben Distribution of the number of students between the capital and the countryside in the 2018/2019 academic year

\begin{tabular}{lccccc} 
& in the 2018/2019 academic year & & \\
& Fóváros & Vidék & Fóváros & Vidék & \\
\hline Tudományegyetemek & 114499 & 111637 & $51 \%$ & $49 \%$ & $100 \%$ \\
Művészeti egyetemek & 3297 & - & $100 \%$ & - & $100 \%$ \\
Alkalmazott tudományegyetemek & 22953 & 19090 & $55 \%$ & $45 \%$ & $100 \%$ \\
Főiskolák & 5567 & 4418 & $56 \%$ & $44 \%$ & $100 \%$ \\
\hline
\end{tabular}

Forrás: Az Oktatási Hivatal adatai alapján saját számítás

Megjegyzés: a fó telephely (székhely) szerinti adatok ${ }^{8}$

\section{Összegzés}

A felsőoktatási felvételi követelmények 2020-ban életbe lépett szigorítása, az emelt szintű érettségi kötelezővé tétele jelentős csökkenést hozott a jelentkezések számában. E csökkenés a felvettek számát is visszavetette, de nem ugyanolyan mértékben, ami a bejutási esélyek növekedésével járt. A bejutási esélyek változása azonban mind a kistérségek, mind az intézmények esetében differenciált, és ez átstrukturálódást eredményez. E folyamatok egyik fontos következménye, hogy bár növekszik bejutási esélyük, a jelentkezők létszámának nagymértékü fogyása miatt - az abszolút számok tükrében - valójában mégis csökken a hátrányos helyzetü régiók fiataljainak bejutása a felsőoktatásba. A másik következmény, hogy a felvételi követelmények szigorítása átalakítja az intézményrendszer struktúráját is, melynek nyomán a fővárosi intézmények dominanciája tovább növekszik.

\section{Jegyzet}

1 A tanulmány lényegében ugyanannak a kutatásnak a másik fele, amely az „Iskolakultúra” című folyóiratban jelent meg. „A felsőoktatási felvételi ingadozásai - avagy az oktatáspolitika társa- 
dalomismeretének hiánya" című írás (Polónyi 2020) az itt is tárgyalt 2020. évi felvételit oktatáspolitikai megközelítésben, az oktatáspolitikai akciók tükrében vizsgálja, nem érintve annak területi rekrutációs összefüggéseit.

2 A 2010-es évek második felében általános eljárás keretében jelentkezett az összes hallgató mintegy 89 százaléka, illetve ebben az eljárásban regisztrálták az adott tanévre felvett hallgatók 88-89 százalékát (Polónyi 2018b).

3 A felvételi eljárás során a tanulók több szakot és intézményt is megjelölhetnek (kivéve a pótfelvételin): ebből adódik ki az összes jelentkezési szám, amit a felvi.hu megad a felvételi adatok sorában. Az azonban az idők folyamán változott, hogy hány helyre lehet egyszerre jelentkezni. Ezért az első helyes jelentkezések számát használom, melyet a felvi.hu ugyancsak közöl. Ez a jelentkezők esetében csak az első helyen megjelölt szakot, illetve intézményt veszi figyelembe ('́gy az első helyes jelentkezők száma lényegében az adott felvételi eljárásban jelentkezők valódi számával egyezik meg, míg az összes jelentkezés annak többszöröse).

4 Miután a felvételi adatbázis továbbra is a kistérségi rekrutáció adatait mutatja be, ezért használtam a korábbi kistérségi komplex mutatót. A kistérségi adatszolgáltatás megszűnése miatt nem állt rendelkezésre frissebb fejlettségi mérőszám, illetve ilyet csak viszonylag jelentős (külön) elemzéssel lehetett volna előállítani. Így lényegében azzal a rejtett feltételezéssel éltem, hogy a 20-20 legfejlettebb és a leghátrányosabb helyzetű kistérség fejlettsége az elmúlt tíz évben egymáshoz - és a többi kistérséghez - viszonyítva nem változott.

5 Kívül esik jelen dolgozat tárgyán e kérdéskör elemzése. Itt csak arra utalok, hogy ha a 2020. évi jelentkezések változását összevetjük azoknak a korábbi években felvetteknek az arányával, akik nyelvvizsgáért, illetve emelt szintű érettségiért többletpontot kaptak, akkor azt találjuk, hogy a 2020. évi jelentkezők számának változása az emelt szintű érettségivel rendelkezők arányával mozog együtt viszonylag erős korrelációval, míg a nyelvvizsgával rendelkezőkével alig. Ha csak a nappali tagozatos hallgatók esetében vizsgáljuk ugyanezt, akkor mindkettőre alacsony korrelációt kapunk: ebből következik, hogy a részidős képzésre jelentkezőket alapvetően az emelt szintü érettségi riasztotta el (Polónyi 2020).

6 Ebben az írásban nem foglalkozom a 2008. évi és a 2013. évi visszaesés okaival: a részleteket illetően lásd például Polónyi (2020) írását.

7 Megjegyzendő, hogy a 3. táblázat alapján számítható átlagos bejutási esélyek eltérnek a 2. táblázatban látott értékektől, mivel a 2. táblázat adatait a kistérségek bejutási esélyeinek átlagaként számítottam ki.

8 Miután az intézmények - a székhelyük mellett - különböző településeken, általában több telephellyel is rendelkeznek, valójában, ha telephelyeiket is figyelembe vesszük, akkor a fóvárosban tanuló hallgatók aránya - Oktatási Hivatal adatai alapján végzett számításaim szerint - 53\% volt a 2018/2019. tanévben.

\section{Irodalom}

Garami E. (2013): Kistérségi jellemzók együttes hatása az oktatás eredményességére és a továbbtanulási döntésekre. PhD-értekezés. Debreceni Egyetem, Debrecen https://dea.lib.unideb.hu/dea/bitstream/ handle/2437/179801/Garami_Erika_Ertekezes-t.pdf?sequence=5\&isAllowed=y (Letöltés 2020.11. 05.)

KSH (2008): Tájékoztató a kiemelten támogatott kistérségekröl. Központi Statisztikai Hivatal, Budapest http://www.ksh.hu/docs/hun/xftp/idoszaki/pdf/kistersegimutato.pdf (Letöltés 2020.12. 10.)

Polónyi I. (2012): Honnan jönnek a hallgatók? Educatio, 2., 244-258.

Polónyi I. (2018a): A hátrányos helyzetű kistérségekben élő fiatalok felsőoktatásba kerülésének esélye. Statisztikai Szemle, 10., 1001-1019. https://doi.org/10.20311/stat2018.10.hu1001

Polónyi I. (2018b): A hazai felsőoktatás felvételi tendenciái és hallgatólétszámának néhány jellemzője. In: Kováts G., Temesi J. (szerk.): A magyar felsőoktatás egy évtizede 2008 - 2017. Budapesti Corvinus Egyetem, Nemzetközi Felsőoktatási Kutatások Központja, Budapest, 111-129. 
Polónyi I. (2020): Harmadik csapás. A felsőoktatási felvételi ingadozásai - avagy az oktatáspolitika társadalomismeretének hiánya. Iskolakultúra, 10., 25-37. https://doi.org/10.14232/ISKKULT. 2020.10.25

\section{Melléklet}

1. táblázat: A leghátrányosabb helyzetű 20 és a legjobb helyzetű 20 kistérség a 2008. évi komplex mutató alapján

Most disadvantaged and best positioned micro-regions in 2008

\begin{tabular}{|c|c|c|c|}
\hline \multicolumn{3}{|c|}{ LHH 20} & \multirow{2}{*}{$\frac{\text { LJH2O }}{\text { Tatabányai }}$} \\
\hline 1 & Abaúj-Hegyközi & 153 & \\
\hline 2 & Bodrogközi & 154 & Mosonmagyaróvári \\
\hline 3 & Sellyei & 155 & Szentendrei \\
\hline 4 & Mezőkovácsházai & 156 & Gárdonyi \\
\hline 5 & Csengeri & 157 & Veszprémi \\
\hline 6 & Sárbogárdi & 158 & Siófoki \\
\hline 7 & Mezőcsáti & 159 & Ráckevei \\
\hline 8 & Ercsi & 160 & Tatai \\
\hline 9 & Fehérgyarmati & 161 & Balatonalmádi \\
\hline 10 & Jánoshalmai & 162 & Hévízi \\
\hline 11 & Ózdi & 163 & Győri \\
\hline 12 & Szikszói & 164 & Balatonfüredi \\
\hline 13 & Edelényi & 165 & Veresegyházi \\
\hline 14 & Hevesi & 166 & Gödöllői \\
\hline 15 & Sásdi & 167 & Szentgotthárdi \\
\hline 16 & Bélapátfalvai & 168 & Pilisvörösvári \\
\hline 17 & Nyírbátori & 169 & Budapesti \\
\hline 18 & Székesfehérvári & 170 & Érdi \\
\hline 19 & Bátonyterenyei & 171 & Dunakeszi \\
\hline 20 & Várpalotai & 172 & Budaörsi \\
\hline
\end{tabular}

Forrás: KSH 2008 
2. táblázat: Az alap- és osztatlan képzésre összesen, nappali tagozatra és a részidős képzésre jelentkezők és felvettek száma

Number of applications and admissions to basic, undivided and full time and part-time training

\begin{tabular}{ccccccc} 
& $\begin{array}{c}\text { AO } \\
\text { jelentkezó }\end{array}$ & $\begin{array}{c}\text { AO } \\
\text { felvett }\end{array}$ & $\begin{array}{c}\text { AON } \\
\text { jelentkezó }\end{array}$ & $\begin{array}{c}\text { AON } \\
\text { felvett }\end{array}$ & $\begin{array}{c}\text { AOR } \\
\text { jelentkezö }\end{array}$ & $\begin{array}{c}\text { AOR } \\
\text { felvett }\end{array}$ \\
\hline 2015 & 78607 & 51670 & 64120 & 40145 & 14487 & 11525 \\
2016 & 83271 & 53999 & 65727 & 41021 & 17544 & 12978 \\
2017 & 82703 & 55225 & 63624 & 41318 & 19079 & 13907 \\
2018 & 84291 & 57068 & 64708 & 42320 & 19583 & 14748 \\
2019 & 88839 & 61041 & 68459 & 44989 & 20380 & 16052 \\
2020 & 69281 & 49640 & 56691 & 39741 & 12590 & 9899 \\
\hline $2019-2019$ & 19558 & 11401 & 11768 & 5248 & 7790 & 6153 \\
$2020 / 2019 \%$ & $78 \%$ & $81 \%$ & $83 \%$ & $88 \%$ & $62 \%$ & $62 \%$ \\
\hline
\end{tabular}

Forrás: felvi.hu adatbázis

AO - alap-és osztatlan képzés

AON - alap-és osztatlan képzés nappali munkarendben

$A O R$ - alap-és osztatlan képzés részidős munkarendben 


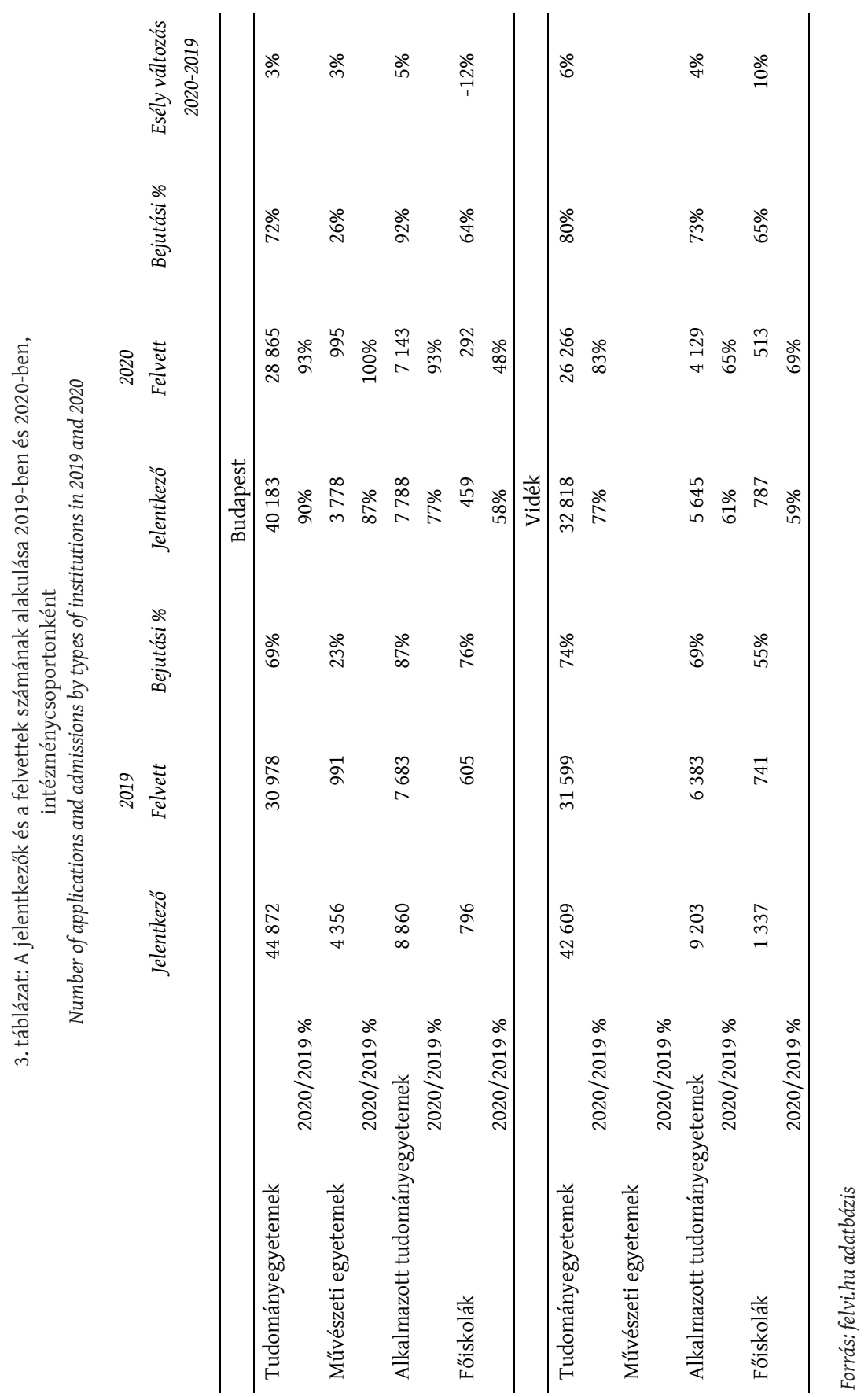

